\title{
GENDER, VOICE, AND LEARNING IN ONLINE COURSE ENVIRONMENTS
}

\author{
David M. Anderson \\ Department of Educational Leadership and Counseling \\ Eastern Michigan University \\ Carol J. Haddad \\ Department of Interdisciplinary Technology \\ Eastern Michigan University
}

\begin{abstract}
A self-selected sample of 109 online students at a midwestern regional university was surveyed and asked to compare expression of voice, control over learning, and perceived deep learning outcomes in face-toface versus online course environments. We found that females experience greater perceived deep learning in online than in face-to-face courses, and that expression of voice appears to contribute to this outcome. This effect did not occur for male students. We also found that professor support and, to a lesser extent, control over one's learning each had positive relationships with perceived deep learning in both course environments. Concern for the feelings of other students did not have a negative impact on voice as was originally hypothesized.
\end{abstract}

\section{KEYWORDS}

Online teaching, online learning, women, gender, voice, postsecondary education

\section{INTRODUCTION}

Online learning has been gaining in popularity at postsecondary schools. In 2000-2001, 56 percent of two- and four-year postsecondary institutions offered distance education courses enrolling an estimated 3,077,000 students overall and 2,876,000 in college-level credit courses, more than double the number of distance college students in 1997-1998 [1]. The type of distance education most commonly offered by colleges and universities was asynchronous learning, in which instruction is offered via the internet; 90 percent of institutions offering distance instruction used this method [1].

A concurrent trend has been the increasing proportion of women in the postsecondary student population. In 1999-2000, women comprised a majority of those earning postsecondary degrees, obtaining 56.3 percent of bachelor's degrees and 57.8 percent of master's degrees, and during the ten-year period of 1988-1998, the number of bachelor's degrees conferred upon men increased by 9 percent, whereas for women this increase was 28 percent [2]. Clearly, it is important to understand how this growing population of students fares in an online learning environment, especially since women enroll in online courses at a higher rate than men [3].

Existing research on gender and online learning paints a mixed picture of whether women fare better or worse in an online environment. In a study sponsored by the American Association of University Women, 
Kramarae [4] concluded that although distance education affords greater flexibility to women seeking to advance academically, it also imposes a "third shift" on them by adding extra work to their lives, which are already filled with job and home responsibilities. However, in a different study of male and female students in asynchronous learning networks (ALN) in university courses, both sexes used ALN in similar ways, had similar positive attitudes about their "computer experience," and expressed a desire to take more courses using computers [5].

To provide an empirical basis for resolving this open question, we conducted an exploratory study at a comprehensive regional state university in the midwestern United States. The purpose of our study was to determine whether female undergraduate and graduate students experience greater voice and perceive more control over learning, more reflective learning, and more positive learning outcomes in internetbased courses than in similar face-to-face courses. We define voice as the degree to which students feel comfortable expressing their views in class and the extent to which they feel their views are heard and valued by other students. We further sought to determine whether students differ on the basis of gender on these outcome measures. This article reports on that research, thereby contributing to a small but growing body of literature on gender and online learning.

\section{THEORETICAL FRAMEWORK}

\section{A. Gender and Classroom Dialogue}

In mixed gender face-to-face classrooms, female students may speak out less frequently and confidently than their male counterparts due to role socialization that encourages girls to be polite and restrained and boys to be assertive and vocal. In addition, even when female students do express their views frequently and with conviction, either they may internally filter their comments or their voices are not heard by others in the class in the same way that male student voices are. Muted group theory explains how this pattern established in childhood can replicate itself in the university classroom; because the "public sphere has been predominantly populated by men and their language, women generally feel less able to participate in public discourse” [6]. Yet we have observed a different dynamic in online as opposed to face-to-face courses: in online courses with required participation in discussion, female students appear less hesitant to engage in dialogue, and this holds true regardless of age or national origin. Online courses encourage students to make well-supported arguments and are forums in which "all voices [are] heard, not just those of the most vocal students" [7] because "nonverbal indications of status are unavailable" in electronic-mediated classroom discussions [8].

Online courses also permit—and often encourage-dialogue and connectedness and therefore complement women's "ways of knowing" [9], since "many women are 'connected' knowers who make sense of reality by relating new knowledge to experience in the context of relationships" [10]. This proposition is bolstered by Witkin's theory of field independence and dependence [11] in which it is postulated that women are more field dependent than men, meaning that they favor learning modes that focus on context and emphasize interpersonal interaction [12]. It is our belief that online courses can, with small class sizes and requirements for internet-based discussion, promote greater peer and studentinstructor interaction and dialogue, an outcome that female students prefer, as discussed in the previous paragraph. Our viewpoint is supported by Gallini and Barron [13], who found that students reported greater communication with their instructor and peers in online than in face-to-face classrooms. This outcome, however, depends on how the online and face-to-face courses are structured. In a study comparing the two course delivery modes in one university program, there was greater student-to-student interaction in face-to-face than in online courses, but this was due largely to the fact that learning group interaction for the online sections transpired via weekly electronic mail rather than in the course web site 
or through electronic conferencing [14]. Therefore, the results of that study do not refute our contention that more communication occurs in online courses than in face-to-face environments.

\section{B. Control Over Learning}

We also theorized that students would feel greater control over their learning in online than in face-to-face courses, and thus contribute greater voice. This control stems from students' ability not only to participate in asynchronous class discussions according to their own schedules but also to access scholarly resources at the touch of a fingertip. As Bandura has stated, whereas in the past "students' educational development was largely determined by the schools to which they were assigned," now "the internet provides vast opportunities for students to control their own learning” [15]. Self-regulated learning is a feature of many online courses, and female students have a stronger association with self-regulated learning than male students do [16].

\section{Reflection and Depth of Perceived Learning}

From our experience as instructors in both online and face-to-face classes, we theorized that students in online courses have greater opportunity for reflection, and thus deeper perceived learning occurs in internet-based courses. When online students commit their thoughts to writing, they are more deliberate than when they spontaneously offer their views in the face-to-face classroom. Also, in many online courses, and certainly in the ones we teach, a good deal of peer learning takes place as students read one another's analyses of weekly readings, thereby expanding the range of viewpoints to which students are exposed. Although this is also a feature of face-to-face classes, the written viewpoints of fellow students posted on internet course sites can be read and re-read throughout the week. Finally, we believe that deeper perceived learning occurs because students can readily find on the World Wide Web rich factual material in support of their arguments, and post these articles and web sites for fellow students to read.

There is some support in the research literature for our belief that deeper perceived learning occurs in online courses than in face-to-face classes. In an ethnographic study comparing a small sample of students' face-to-face and online learning experiences, Meyer [17] found that one advantage of web-based threaded discussions cited by students was the opportunity to reflect before speaking. Although reflection is thought to be an indicator of higher order thinking, Meyer is quick to add that students view online learning differently depending on their strengths and learning styles. Those who learn and process information verbally and who enjoy the give-and-take nature of classroom discussion "may feel disadvantaged in the online setting” compared to students who need to reflect before offering an answer.

In another study, Card and Horton [14] discovered that when engaged in interaction to explain concepts to one another, students in face-to-face classes generally relied upon their own experiences and opinions, whereas those in computer-mediated classes tended to cite literature and integrate it with their experiences. Smith, Ferguson, and Caris [18], in a study comparing the experience of professors teaching in both web-based online and face-to-face college courses, concluded that the "emphasis on the written word encourages a deeper level of thinking in online classes," resulting in "more profound" learning.

Warschauer [19] believes that online courses, which are "time-and-place independent" and which permit students to access "hypermedia-based information" at will, allow for "more in-depth analysis and critical reflection, because e-mail can be answered more deliberatively than synchronous messages." Computermediated learning environments also encourage active learning, in which students are expected to write about what they learn and relate it to past and current experience rather than passively listen to lectures 
and memorize facts for exams [20]. Such environments permit online learning communities to emerge through the mutual support that is offered by way of threaded discussion [21].

\section{Research Model and Hypotheses}

Our research model proposes a path analytic model by which the learning process influences perceived learning outcomes. The learning process in our model refers to four variables that describe what occurs during a course: (1) student control over learning (control); (2) student concern for others (concern); (3) the degree to which students feel they have access to the instructor and support from the instructor (professor support); and (4) the degree to which students feel comfortable expressing their views in class and the extent to which they feel their views are heard and valued by other students (voice). The ultimate outcome or result is depth of perceived learning (as measured by the opportunity to reflect on what has been learned). Our model assumes that the effects of control, concern, and professor support are mediated by voice, and that all four variables have a direct effect on perceived learning. This model is depicted graphically in Figure 1.

Figure 1: Research Model

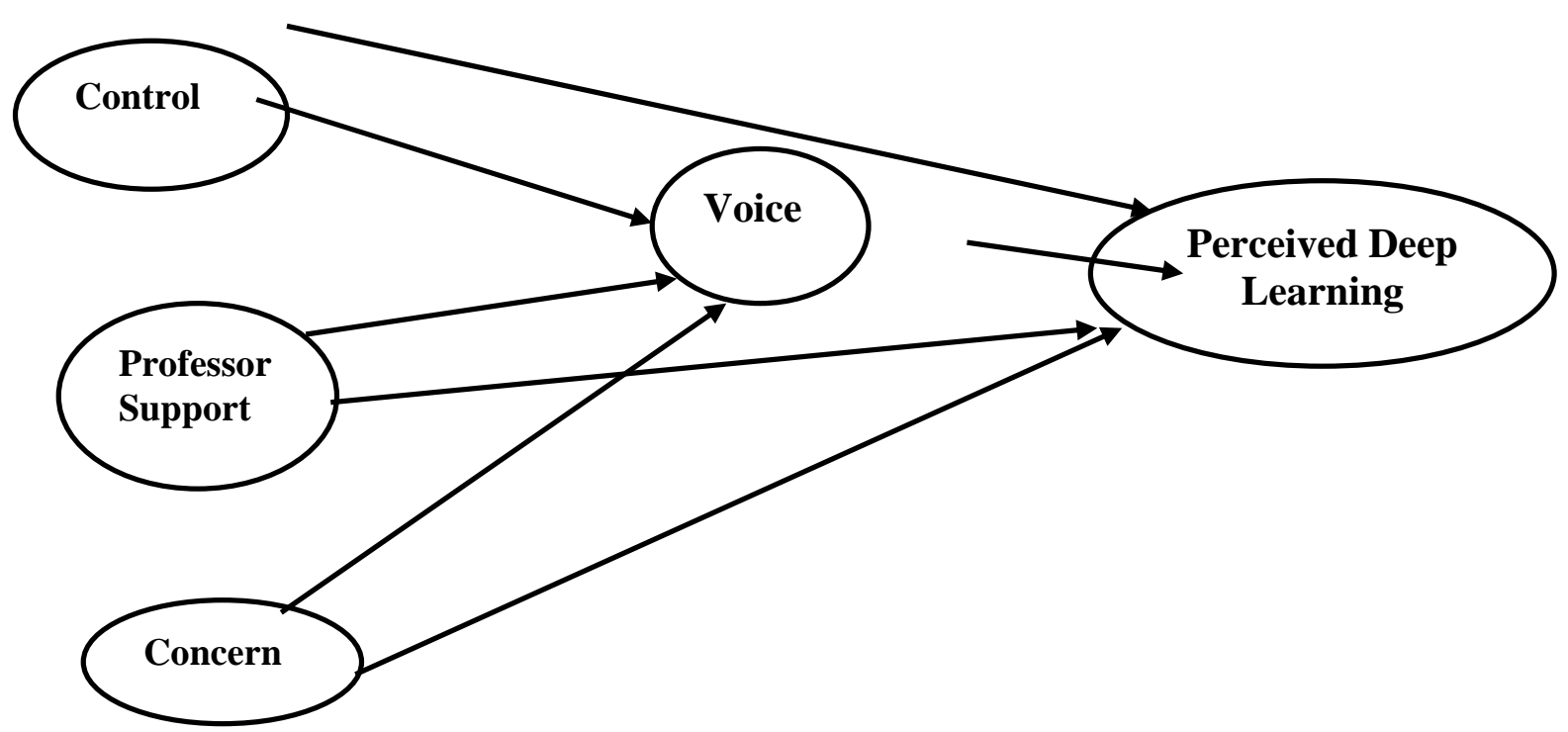

Our literature-supported theoretical framework and the model above led to the generation of five hypotheses.

- Hypothesis 1: Students of both genders experience greater perceived deep learning in online than in face-to-face courses.

- Hypothesis 2: Female students express voice more strongly in online than face-to-face courses, and this contributes in turn to greater perceived deep learning.

- Hypothesis 3: Professor support contributes, both indirectly through voice and directly, to greater perceived deep learning.

- Hypothesis 4: Control over learning contributes, both indirectly through voice and directly, to greater perceived deep learning.

- Hypothesis 5: Concern for the feelings of classmates contributes, both indirectly through voice and directly, to less perceived deep learning. 


\section{METHODOLOGY}

\section{A. Research Site}

Our study was conducted at a medium-sized regional comprehensive public university in the midwestern United States. This university enrolled 22,672 students during the winter 2002 semester in which this study was conducted, 76 percent of whom were undergraduates and 24 percent of whom were graduate students. Women comprised 61 percent of the total student body, although in online courses the student population was 69 percent female and 31 percent male. The average student-faculty ratio for the university as a whole was 19:1 for both face-to-face and online courses. As a regional comprehensive university, the research site was far more representative of the U.S. four-year postsecondary student population than would be the case at a larger Carnegie I institution or a smaller liberal arts college. Average freshman grade point average was 3.01, and average SAT score was 1006. Although students come from 42 states and 90 countries, 90 percent of them come from the state in which the regional university is located.

\section{B. Research Design and Data Collection}

Data were collected from students enrolled in online courses during a single semester (winter 2002). At the end of that semester there were 1,064 students enrolled in 55 online course sections taught by 31 faculty. During the final two weeks of the semester, we sent electronic mail messages to the online faculty requesting that they forward to their students a message from us telling them of our study and asking for their voluntary participation in an online survey developed specifically for this project. Of the 31 faculty who taught online courses that semester, 9 agreed to forward our request. This reduced the number of students asked to participate to 321, of which 109 responded with complete data (Table 1). The average class size in the course sample was 17 , which compared closely to the overall student-faculty ratio of 19:1. As an incentive, all respondents were entered into a raffle for a one hundred dollar gift certificate for use at the campus bookstore. To protect student confidentiality, all responses went into a database maintained by the campus Center for Research Support. These data files were collected by means of an online survey constructed using Inquisite software.

Table 1: Online Population and Sample Statistics

\begin{tabular}{|l|l|l|l|l|}
\hline & \# Students & \# Courses & \% Female & \% Male \\
\hline Total Online Population & 1064 & 55 & 69 & 31 \\
\hline Course Sample & 321 & 19 & 72 & 28 \\
\hline Respondent Sample & 109 & 19 & 73 & 27 \\
\hline
\end{tabular}

We developed the survey instrument to measure constructs contained in our theoretical framework depicted in Figure 1. The constructs, the specific questions generated to measure them, and the Chronbach's alpha measure of scale reliability appear in Table 2. The Chronbach alpha coefficients indicate strong reliability of our research measures. Students were asked to answer each set of the above questions twice-once pertaining to their current online course and a second time to report their experience in a face-to-face course with a similar teaching style or content. This approach had a distinct advantage: it allowed us to use a sample of perfectly matched online and face-to-face students, and it controlled for differences in intrinsic student characteristics, such as learning style, perceptions of learning, background culture, and so forth. Five-point Likert scales served as the response categories: $1=$ strongly disagree, $2=$ disagree, $3=$ neutral, $4=$ agree, and $5=$ strongly agree. 
The factors listed in Table 2 were combined in two ways: (1) principal components analysis and (2) linear combination with equal weighting. There were no significant differences between the two sets of results, so the second approach was used for ease of interpretation. The final factors from the second approach were tested for reliability using a scale analysis. In order to test our hypotheses, we performed a set of $t$ tests and a path analysis to examine the relationships captured in our conceptual framework, illustrated in Figure 1.

We used student perception as opposed to independent assessments such as test results as our measure of deep learning since there were no comparable independent student assessment data across courses. The Chronbach alpha for perceived deep learning presented in Table 2 indicates that the questionnaire items we used reliably measure this construct.

Table 2: Questionnaire Constructs and Measures

\begin{tabular}{|c|c|c|}
\hline Construct & $\begin{array}{l}\text { Chronbach's } \\
\text { Alpha }\end{array}$ & Measures \\
\hline $\begin{array}{l}\text { Control } \\
\text { learning }\end{array}$ & $\begin{array}{l}.80 \text { (online) } \\
.83 \text { (f-to-f) }\end{array}$ & $\begin{array}{l}\text { I felt that the course design was flexible enough to fit the way } \\
\text { I learn. } \\
\text { I felt I was able to learn at my own pace. }\end{array}$ \\
\hline Concern for others & $\begin{array}{l}.70 \text { (online) } \\
.70 \text { (f-to-f) }\end{array}$ & $\begin{array}{l}\text { My concern about the feelings of my classmates affected my } \\
\text { expression of views. } \\
\text { In class discussions I tried to say positive things to support } \\
\text { my classmates' feelings. } \\
\text { I withheld or softened my views when I thought they would } \\
\text { offend others. }\end{array}$ \\
\hline Professor support & $\begin{array}{l}.87 \text { (online) } \\
.88 \text { (f-to-f) }\end{array}$ & $\begin{array}{l}\text { I felt that I had access to the instructor in the course. } \\
\text { I felt supported by the instructor in the course. }\end{array}$ \\
\hline Voice & $\begin{array}{l}.91 \text { (online) } \\
.93 \text { (f-to-f) }\end{array}$ & $\begin{array}{l}\text { I was comfortable expressing my views on course topics. } \\
\text { Course content and format allowed multiple views to be } \\
\text { expressed. } \\
\text { I was comfortable expressing controversial views on course } \\
\text { topics. } \\
\text { I felt that my views were heard by other students in the class. } \\
\text { I felt that my contributions were valued by other students in } \\
\text { the class. } \\
\text { I felt free to choose words that really expressed how I felt } \\
\text { about course topics. } \\
\text { I was expected to share my opinions about course topics. } \\
\text { I felt that my views were heard by the instructor. } \\
\text { I felt that my contributions were valued by the instructor. }\end{array}$ \\
\hline $\begin{array}{l}\text { Perceived } \\
\text { learning }\end{array}$ & $\begin{array}{l}.85 \text { (online) } \\
.82 \text { (f-to-f) }\end{array}$ & $\begin{array}{l}\text { Course activities encouraged my to think deeply about the } \\
\text { course content before sharing my ideas. } \\
\text { Course activities caused me to reflect on what I learned after } \\
\text { the assignment due dates. } \\
\text { I learned a lot in the course. }\end{array}$ \\
\hline
\end{tabular}




\section{EMPIRICAL RESULTS}

We received complete responses from 109 students, 80 females and 29 males. This provided us with a response rate of 34 percent, and with a gender breakdown that was fairly representative of the online student population for that semester (Table 1). The mean age of respondents was 28.14, with the distribution clustered in the 18 to 29 age range. Of all respondents, 68.1 percent were age 18 to 29, 18.7 percent were 30 to 39, 7.2 percent were 41 to 49 , and 5.4 percent were 50 to 52 . Seventy-one percent of respondents were Caucasian; 11.5 percent Black; 7 percent Asian; 1.8 percent Hispanic, Arab, or Native American; and 5 percent self-identified as multiracial or biracial.

Our own experience as online instructors and our literature review led us to believe that there might be differences between women and men in terms of their levels of control, concern, voice, perceived professor support, and deep learning in face-to-face versus online courses. In order to explore these gender effects, we ran $t$ tests to compare means between face-to-face and online courses for both genders. We found significant differences in only two: voice and perceived deep learning (Table 3). The data indicate that females perceived greater voice and more deep learning in online than in face-to-face courses, whereas no significant perceived difference existed for males.

Table 3: Effect of Gender in Online and Face-to-Face Courses

\begin{tabular}{|l|l|l|l|l|l|}
\hline & Online & Face-to-face & Mean difference & Std.Err. & Sig. \\
\hline Women's Voice & 36.5375 & 33.2750 & $3.2625^{* * *}$ & .9890 & .001 \\
Men's Voice & 35.2414 & 33.9310 & 1.3103 & 2.4571 & .598 \\
\hline Women's Control & 8.0625 & 6.2626 & $1.8000^{* * *}$ & .3465 & $<.001$ \\
Men's Control & 8.5517 & 6.4828 & $2.0690^{* * *}$ & .5412 & $<.001$ \\
\hline Women’s Concern & 9.4125 & 10.1375 & $-.7250^{*}$ & -1.3434 & .022 \\
Men's Concern & 9.4828 & 10.0690 & -.5862 & -1.4153 & .159 \\
\hline Women's Support & 8.4750 & 7.8875 & $.5875^{*}$ & .2649 & .029 \\
Men's Support & 7.7586 & 8.2414 & -.4828 & .6558 & .468 \\
\hline Women's Learning & 12.5250 & 11.6125 & $.9125^{* *}$ & .2875 & .002 \\
Men's Learning & 12.1379 & 11.6897 & .4483 & .7064 & .531 \\
\hline
\end{tabular}

* Significant at the .05 level

** Significant at the .01 level

*** Significant at the .001 level

Based on these relationships, we regressed deep learning on the four process variables for both online and face-to-face environments, and we regressed voice on the other three process variables for both environments. The results are provided in Figures 2 and 3. As the data indicate, voice is the most powerful direct predictor of perceived deep learning in both environments. Since women's voice is greater in the online environment, their perceived deep learning is also greater. 
Figure 2: Online Environment Regression Coefficients for Both Genders

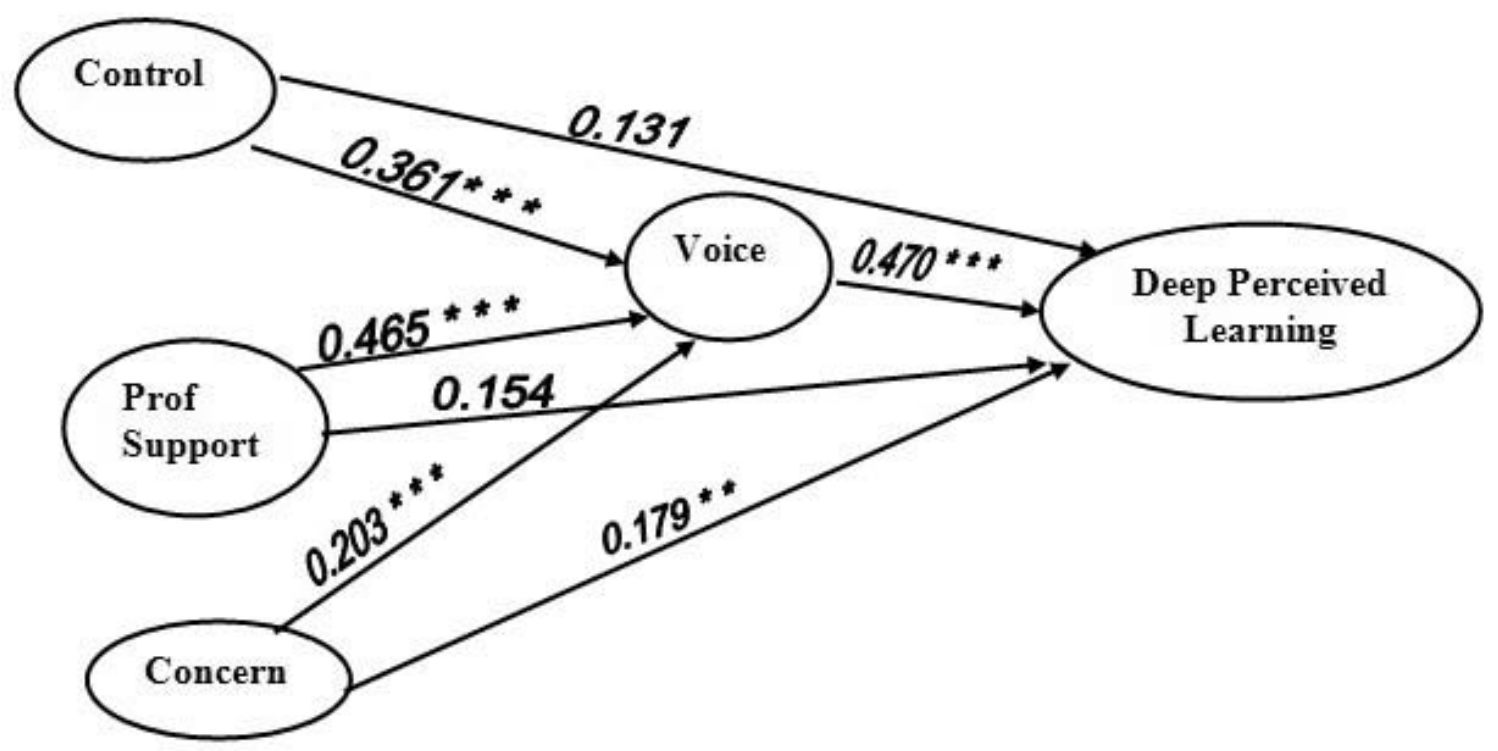

\section{* * Significant at the .01 level \\ *** Significant at the .001 level}

Although professor support and student control over learning each had positive impacts on voice in both course environments, professor support had the largest impact. While professor support had a direct significant effect on deep perceived learning in the face-to-face classroom, its effect on perceived learning was mediated by voice in the online classroom.

Figure 3: Face-to-face Environment Regression Coefficients for Both Genders

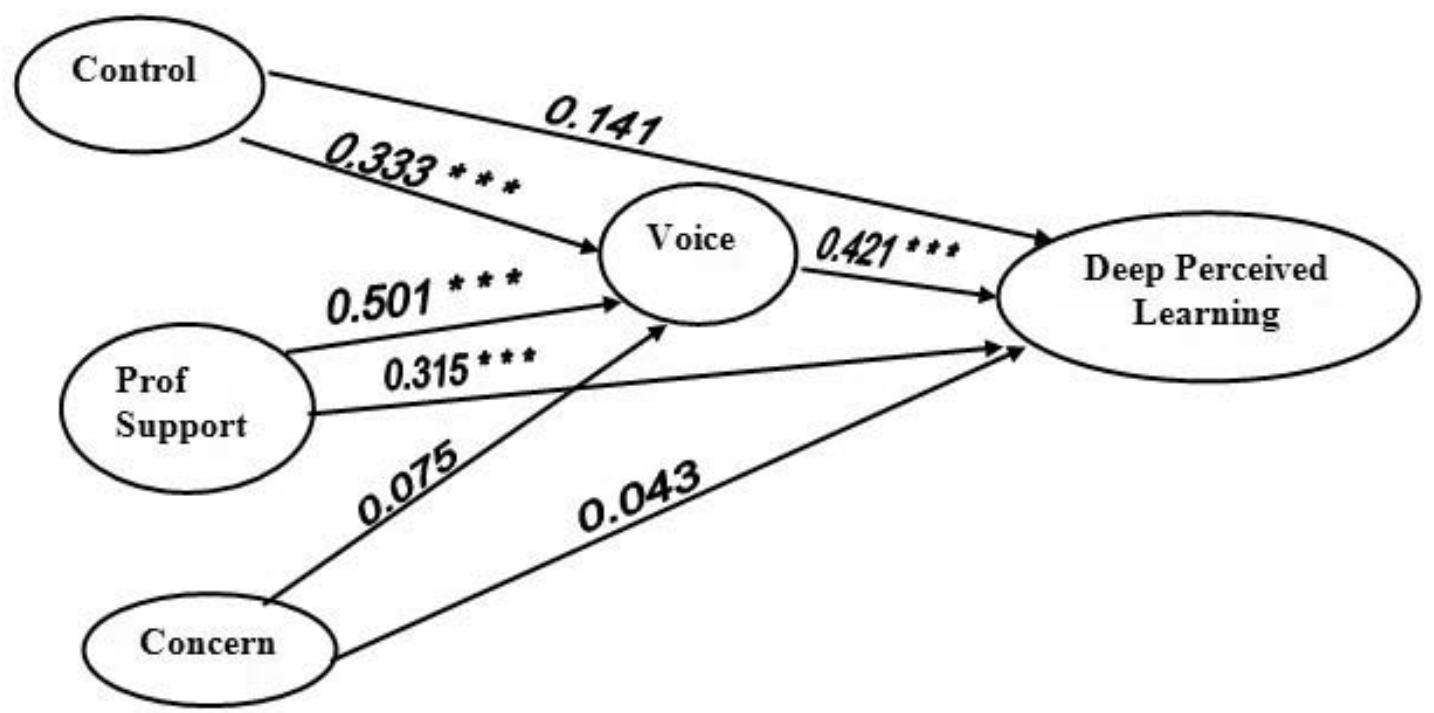

*** Significant at the .001 level 
Concern for the feelings of classmates did not have a negative impact on voice, as we had hypothesized. It had a small positive impact in the online environment and no significant impact in the face-to-face environment.

In summary, four hypotheses were partially supported by the data, and one hypothesis was not supported by the data. Specifically, females experienced greater perceived deep learning in online than in face-toface courses, as was proposed in Hypothesis 1, whereas males did not. Female students expressed voice more strongly in online than in face-to-face courses, and this contributed in turn to greater perceived deep learning, as was proposed in Hypothesis 2, but this was not true for males. Professor support contributed indirectly through voice to greater perceived deep learning, as was proposed in Hypothesis 3, but there was no direct effect. Similarly, control over learning contributed indirectly through voice to greater perceived deep learning, as proposed in Hypothesis 4, but there was no direct effect. Finally, concern for the feelings of classmates did not contribute-either indirectly through voice or directly-to less perceived deep learning.

\section{DISCUSSION}

As we predicted, females experience deeper perceived learning in online than in face-to-face courses (Hypothesis 1). Men do not, although this may be due to insufficient sample size. Our research suggests that, for females, this greater perceived learning occurs because of the role that voice plays in strengthening perceived deep learning in both online and face-to-face courses. Males did not report significant differences in voice or perceived deep learning in online as compared to face-to-face courses. Thus, female students seem to experience more voice in online environments as compared to face-to-face courses, and this contributes in turn to greater perceived learning for females as compared to male students (Hypothesis 2). Voices that may not emerge in a face-to-face classroom due to gender-based role socialization, cultural differences, or individual personality traits like shyness are heard in the online course because students are required to post analytical viewpoints about weekly topics and readings, except in the most technical of courses.

Interestingly, students of both genders also report a greater sense of control over their learning online. Most if not all of the online courses taught during the semester in which the survey was administered were primarily asynchronous as opposed to synchronous, enabling students to log into lectures and complete weekly assignments any time of the day or night. This greater sense of control was associated with higher perceived deep learning.

On the other hand, contrary to our prediction, students reported less concern for the feelings of their classmates in online than in face-to-face courses. We had hypothesized that because students in online courses cannot see the non-verbal cues of their classmates, they would temper their remarks so as not to offend them. In actual fact, the opposite seemed to be the case in our study, suggesting that in a face-toface classroom, students' ability to read the facial expressions and body language of their peers heightens their sense of concern for others to a greater extent than is true in an online course. However, concern for the feelings of others was not a consistent predictor of perceived deep learning; it was a significant predictor (indirectly) in online but not in face-to-face settings.

Professor support had a greater indirect effect (as mediated by voice) on perceived deep learning than did control over learning, although both of their direct effects were insignificant. The direct effect of voice on perceived learning was significant. This finding suggests that, contrary to some professors' concerns that they might be rendered redundant by online course formats, their contribution is in fact vital to student learning because it impacts student voice. The sense of voice, and consequently learning success, of 
female online students appears to depend upon the access they feel they have to instructors and the extent to which they feel supported by professors in online courses. This finding is not surprising, since online instructors typically respond to student concerns and mail messages at all times of the day and night, and not only during office hours.

It is interesting to note, however, that there is a gender difference in the extent to which students experience professor support, insofar as women experience more professor support online than in face-toface classrooms, whereas no significant difference in experience exists for men. This finding may be due to the fact that female students in online courses are more willing to reach out to their professors than they are in face-to-face environments where role socialization inhibits them from speaking out, even to seek help.

This is consistent with muted group theory, for as we asserted previously, female students typically speak out less frequently and confidently in mixed gender face-to-face classrooms than do their male counterparts because of role socialization that encourages girls to be polite and restrained and boys to be assertive and vocal. It is important to note that a heightened sense of concern for others does not diminish voice in either classroom environment.

What is surprising, though, is the fact that professor support influences voice more strongly than does the flexibility of the online course environment. This finding counters the popular belief that the flexibility of online courses is the single most attractive characteristic of this learning environment. Professor support also compensates for the difficulty that field-dependent students have been found to have with distance learning, which is thought to allow "limited contact [with] and direction from teachers" [22]. In our experience, we have more day-to-day contact via electronic mail with online students than with face-toface students, and our empirical findings counter the presumption that distance education students "have less access to academic assistance” [22] and must direct their own learning without instructor support.

Some limitations suggest directions for future research. First, it would be better to use a sample of students enrolled in online and face-to-face course matched on equivalent contextual factors (e.g., course content, teaching style, or class size) in the same semester. However, in practice, this is difficult to accomplish for a large sample size in a single university setting. Future research should include a larger sample of universities and involve the collection of data on important contextual factors. This approach would also address the sample size limitations of our analysis and would provide greater variation on class size, which tended to be small at the institution studied. Another issue is that self-perception of deep learning is arguably a less desirable measure than formal authentic assessments. Future research could implement consistent and reliable authentic assessments for deep learning across the entire sample. Next, although the reliability coefficients for our survey constructs were sufficiently high, additional items for some constructs would strengthen the survey instrument. Finally, our study may include some bias due to respondent self-selection. Future research should use a random sample of students.

\section{CONCLUSION}

This study contributes to the scholarship on gender and online learning by empirically measuring voice and determining the relative impact of voice on perceived learning outcomes. As we had predicted, women fare well in the online course environment, which provides them with opportunities for selfexpression that role socialization may inhibit in the face-to-face environment. As with all research, this study has limitations as described above, and we have suggested directions for future research. Nonetheless, these findings are valid in spite of these limitations because our theory-based measures were 
confirmed by statistical tests for reliability, and the percentage of male and female respondents was proportionate to the population of online learners during the semester the study was conducted.

\section{REFERENCES}

1. Waits, T., and Lewis, L. Distance Education at Degree-Granting Postsecondary Institutions: 2000-2001. National Center for Education Statistics, NCES 2003-017. Washington, DC: U.S. Department of Education, 2003, pp v, 3, 6. Online: http://nces.ed.gov/pubs2003/2003017.pdf.

2. National Center for Education Statistics. Digest of Education Statistics, 2000, Table 248. Washington, DC: U.S. Department of Education, 2000. Online: http://nces.ed.gov/fastfacts/display.asp?id=72.

3. Thompson, M. M. Distance learners in higher education. In C.C. Gibson (ed.), Distance Learners in Higher Education: Institutional Responses for Quality Outcomes, 9-24. Madison, WI: Atwood Publishing, 1998.

4. Kramarae, C. The Third Shift. Women Learning Online. Washington, DC: American Association of University Women Educational Foundation, 2001.

5. Ory, J. C., C. Bullock, and K. Burnaska. Gender similarity in the use of and attitudes about ALN in a university setting. Journal of Asynchronous Learning Networks 1 (1): 1-16, 1997.

6. Wood, J. T. Communication Theories in Action. An Introduction, 276. 2nd Edition. Belmont, CA: Wadsworth, Thomson Learning, 2000.

7. Poole, D. M. Student participation in a discussion-oriented online course: a case study. Journal of Research on Computing in Education 33 (2): 162-177, 2000.

8. Schleiter, M. K. Using computer conferencing to break down racial and gender barriers in the college classroom. Feminist Collections: A Quarterly of Women's Studies Resources 17 (2): 16, 1996.

9. Belenky, M. F., B. M. Clinchy, N. R. Goldberger, and J. M. Tarule. Women's Ways of Knowing: The Development of Self, Voice, and Mind. New York: Basic Books, 1986.

10. Kerka, S. Women, human development, and learning. ERIC Digest No: ED358379. Columbus, OH: ERIC Clearinghouse on Adult Career and Vocational Education, 1993: 3. Online: http://www.ed.gov/databases/ERIC_Digests/ed358379.html.

11. Witkin, H. A., C. A. Moore, D. R. Goodenough, and P. W. Cox. Field-dependent and fieldindependent cognitive styles and their educational implications. Review of Educational Research 47: 1-64, 1977.

12. Murphy, H. J., B. Casey, and J. D. Young. Field dependence/independence and undergraduates' academic performance in an information management program. College Student Journal 31: 45-50, 1997.

13. Gallini, J. K., and D. D. Barron. Participants' perceptions of Web-infused environments: a survey of teaching beliefs, learning approaches, and communication. Journal of Research on Technology in Education 34 (2): 139-156, 2001/02.

14. Card, K. A., and L. Horton. Providing access to graduate education using computer-mediated communication. International Journal of Instructional Media 27 (3): 235-245, 2000.

15. Bandura, A. Social cognitive theory: An agentic perspective. Annual Review of Psychology 52: 126, 2001.

16. Joo, Y., M. Bong, and H. Choi. Self-efficacy for self-regulated learning, academic self-efficacy, and Internet self-efficacy in Web-based instruction. Educational Technology Research and Development 48 (2): 5-17, 2000.

17. Meyer, K. A. Face-to-face versus threaded discussions: The role of time and higher-order thinking. Journal of Asynchronous Learning Networks 7 (3): 1-11, 2003.

Online: http://www.sloan-c.org/publications/jaln/v7n3/v7n3_meyer.asp. 
18. Smith, G. G., D. Ferguson, and M. Caris. Teaching college courses online vs. face to face. T.H.E. Journal 28 (9): 18-26, 2001.

19. Warschauer, M. Computer-mediated collaborative learning: Theory and practice. The Modern Language Journal 81: 470-481, 1997.

20. Van Dusen, G. C. Digital dilemma: Issues of access, cost, and quality in media-enhanced and distance education. ASHE-ERIC Higher Education Reports 27 (5): 1-120, 2000.

21. Caverly, D. C., and L. MacDonald. Online learning communities. Journal of Developmental Education 25 (3): 36-37, 2002.

22. Luk, S. C. The relationship between cognitive style and academic achievement. British Journal of Educational Technology 29 (2): 7, 137-147, 1998.

\section{ACKNOWLEDGEMENTS}

We gratefully acknowledge the contributions of Dr. Stuart Karabenick of the Center for Research Support at Eastern Michigan University (EMU), who offered invaluable advice on our research model and data analysis strategies; his graduate assistant Kanwal Jit, who helped us to migrate our survey instrument to the World Wide Web; Jody Cebina, EMU's Coordinator of Distance Learning, who helped us make contact with online instructors during the semester in which we collected data and provided valuable data on the population size; and Dr. Selva Staub of EMU's Office for Research Development, who offered assistance with our review of the research literature.

\section{ABOUT THE AUTHORS}

David M. Anderson is Associate Professor in the Department of Educational Leadership and Counseling at Eastern Michigan University in Ypsilanti, Michigan. He received his bachelor's degree in physics from Carleton College, a Master of Science degree in physics from the University of Michigan, and his doctorate in education from the University of Michigan. He has worked for three organizations in the area of technology and education: the Bureau of Accreditation and School Improvement Studies, the National Science Foundation's State Systemic Initiative in South Dakota, and the National Board for Professional Teaching Standards. He has also worked with a two universities-Salisbury University and Eastern Michigan University - to develop several courses in the area of technology in education, including a master's program in technology in education.

Carol J. Haddad is a Professor in the Department of Interdisciplinary Technology at Eastern Michigan University. She holds a BA in education, an MS in labor studies, and a $\mathrm{PhD}$ in education from the University of Michigan. She has been teaching online for nearly a decade, including courses on women and technology for the women's studies program and on managing educational technology for the Department of Leadership and Counseling. She has also served as an evaluator for two major projects designed to integrate web resources into K-12 teaching. She serves as Interim Associate Director for the College of Technology's PhD program and has held senior administrative positions with the American Society for Training and Development and the Industrial Technology Institute, as well as a tenured faculty position at Michigan State University. 